\title{
IRON BIOMINERALS: AN OVERVIEW
}

\author{
Richard B. Frankel \\ Department of Physics \\ California Polytechnic State University \\ San Luis Obispo, CA 93407
}

\section{INTRODUCTION}

Biomineralization processes, by which organisms form inorganic minerals, are broadly distributed and occur in almost every phylum of the biological world $1,2,3$. There is a large diversity of minerals formed, with over 60 currently known 1 . The cations of the most widely occuring minerals are the divalent alkaline earths $\mathrm{Mg}, \mathrm{Ca}, \mathrm{Sr}$ and $\mathrm{Ba}$. These are paired with the anions carbonate, hydroxide, oxalate, oxide, phosphate, sulfate and sulfide. Silica, hydrous silicon oxide, also occurs widely in algae (Table 1). These minerals function as exo- and endoskeletons, cation storage, lenses, gravity devices and in other roles in various organisms.

\section{IRON BIOMINERALS}

Minerals of iron are also known to occur in many organisms. This is due perhaps, to the important role of iron in many metabolic processes, and to the difficulty for organisms posed by the toxic products of ferrous iron oxidation by $\mathrm{O}_{2}$ together with the insolubility of ferric iron at neutral $\mathrm{pH}$. Formation of iron minerals allows organisms to accumulate iron for future metabolic needs while avoiding high intracellular concentrations of ferrous iron. Other attributes of iron biominerals that are potentially useful to organisms include hardness, density and magnetism.

An important class of iron biominerals are the ferric hydroxides or oxyhydroxides, which occur as amorphous, colloidal precipiates, as quasicrystalline minerals such as ferrihydrite, or as crystalline minerals such as lepidocrocite or goethite (Table 2). Amorphous iron oxy-hydroxides are found in the sheaths and stalks produced by the so-called iron bacteria, Leptothrix and Gallionella, which utilize the oxidation of ferrous ions by $\mathrm{O}_{2}$ as a source of 
Table 1. Major non-transition metal minerals formed by organismsa.

\begin{tabular}{lll}
\hline Mineral & Formula & Organism/function \\
\hline
\end{tabular}

Calcium carbonate:

Calcite

Aragonite

Vaterite

Amorphous

Calcium phosphate:

Hydroxyapatite

Octa-calcium

phosphate

Amorphous

Calcium oxalate

Whewellite

Weddellite
$\mathrm{CaCO}_{3}$

$\mathrm{CaCO}_{3}$

$\mathrm{CaCO}_{3}$

$\mathrm{CaCO}_{3} \cdot \mathrm{nH}_{2} \mathrm{O}$

$\mathrm{Ca} 10\left(\mathrm{PO}_{4}\right)_{6}(\mathrm{OH})_{2}$

$\mathrm{Ca}_{8} \mathrm{H}_{2}\left(\mathrm{PO}_{4}\right)_{6}$

?

$\mathrm{CaC}_{2} \mathrm{O}_{4} \cdot \mathrm{H}_{2} \mathrm{O}$

$\mathrm{CaC}_{2} \mathrm{O}_{4} \cdot 2 \mathrm{H}_{2} \mathrm{O}$

$\mathrm{CaSO}_{4}$

$\mathrm{BaSO}_{4}$

$\mathrm{SrSO}_{4}$
Algae/exoskeletons

Trilobites/eye lens

Fish/Gravity device

Molluscs/exoskeleton

Ascidians/spicules

Plants/Ca store

Vertebrates/endoskeleton, teeth, calcium store

Vertebrates/precursor phase in bone

Mussels/Ca store

Vertebrates/precursor phase in bone

Plants/calcium store

Plants/calcium store

Jellyfish larve/ gravity device Algae/gravity device Acantharia/cellular support

Silicon dioxide:

Silica

$\mathrm{SiO}_{2} \cdot \mathrm{nH}_{2} \mathrm{O}$

Algae/exoskeletons

aAdapted from reference 3 .

energy ${ }^{4}$. Amorphous oxy-hydroxides are also found, for example, together with silica in dermal granules in the marine invertebrate Molpadia (Holothuroidea) 5 . The quasi-crystalline ferric oxy-hydroxide ferrihydrite is found in many organisms in the cores of the iron storage protein ferritin 6,7. Ferritin proteins from several bacteria, known as the bacterioferritins 8,9 , contain a somewhat less crystalline ferric oxy-hydroxide-phosphate in their cores ${ }^{8}$. Highly crystalline lepidocrocite and goethite are found in the radular teeth of certain molluscs, the limpets and chitons ${ }^{10,11 .}$

Another important iron biomineral is the iron oxide magnetite, $\mathrm{Fe}_{3} \mathrm{O}_{4}$. Magnetite has a cubic, inverse spinel structure and is ferrimagnetic at ambient temperature. It is also dense $\left(5.1 \mathrm{~g} / \mathrm{cm}^{3}\right)$ and hard. Uniformly-sized particles of magnetite, often arranged in chains, are found in magnetotactic bacteria ${ }^{12-16}$. The particles are often, if not always, enclosed in membrane vesicles; a particle and its enveloping membrane are known as a magnetosome ${ }^{12}$. Magnetite is also 
Table 2: Iron Biominerals ${ }^{\mathbf{a}}$

Mineral

Formula

Organism/Function

Iron oxy-hydroxides:

Ferrihydrite

$5 \mathrm{Fe}_{2} \mathrm{O}_{3} \cdot 9 \mathrm{H}_{2} \mathrm{O}$

Many organisms/

Lepidocrocite

$\gamma-\mathrm{FeOOH}$

Goethite

$\alpha-\mathrm{FeOOH}$

Amorphous

$\mathrm{Fe}_{2} \mathrm{O}_{3} \cdot \mathrm{nH}_{2} \mathrm{O}$

Fe storage

Chitons and Limpets/ radular teeth

Chitons and Limpets/ radular teeth

Bacteria/sheath

Iron oxides:

Magnetite $\quad \mathrm{Fe}_{3} \mathrm{O}_{4}$

Bacteria/magnetotaxis, metabolic byproduct

Chitons/radular teeth

Salmon, Honeybees, etc./

?

Iron sulfides:

Greigite

$\mathrm{Fe}_{3} \mathrm{~S}_{4}$

Bacteria/magnetotaxis

Pyrite

$\mathrm{FeS}_{2}$

Pyrrhotite $\quad \mathrm{Fe}_{1-\mathrm{x}} \mathrm{S}$

Bacteria/Fe storage (?), metabolic byproduct

Bacteria/magnetotaxis

Iron carbonate:

Siderite

$\mathrm{FeCO}_{3}$

Bacteria/metabolic byproduct

Iron phosphate:

Vivianite

$\mathrm{Fe}_{3}\left(\mathrm{PO}_{4}\right)_{2}$

Bacteria/metabolic byproduct

Ferric hydrous

phosphate

$\mathrm{FePO}_{4} \cdot \mathrm{nH}_{2} \mathrm{O}$

Bacteria/Fe storage

Adapted from reference 3.

found in the radular teeth of chitons 10,11 , and has been found in organisms as diverse as honeybees and salmon ${ }^{17}$. It is the basis for the magnetotactic response in bacteria 12 , and its function in the radular teeth of chitons is presumably related to its harclness. The function of magnetite in organisms other than bacteria and chitons is still unknown but is possibly related to sensing of the magnitude or direction of the geomagnetic field.

The production of iron sulfides in marine sediments is a byproduct of sulfate reduction by bacteria, and the crystalline products, known as framboidal iron pyrites, have been studied for many years 18 . Jones et al. ${ }^{19}$ reported intracellular, amorphous iron sulfides in some sulfate-reducing bacteria. More recently, crystalline particles of the iron sulfides greigite and pyrite ${ }^{20}$, and pyrrhotite 21 , have been reported in magnetotactic bacteria from sulfidic environments. These are related to the magnetotactic response of these organisms, and possibly to other, metabolic, functions as well. Greigite, the thiospinel of iron, is isomorphous with magnetite, and is ferrimagnetic at 
ambient temperature. Pyrrhotite has an hexagonal defect structure, and its magnetic properties depend on the ordering of the defects. Pyrite is nonmagnetic.

Ferrous carbonate and ferrous phosphate have been detected in cultures of dissimilatory iron-reducing bacteria ${ }^{22}$ and magnetotactic bacteria ${ }^{23}$, respectively. They are presumably byproducts of the export of ferrous ions into the medium and have no known functional significance.

\section{BIOMINERALIZATION}

Lowenstam ${ }^{24}$ has distinguished two modes of biomineraliztion, namely, biologically-induced mineralization (BIM) and biologically controlled mineralization (BCM) (also referred to as boundary-organized biomineralization $(\mathrm{BOB}) 25)$. In the former processes, cellular export of metabolic products results in extracellular mineral formation with ions in the enviroment. In the latter process, the mineral phases are deposited in or on preformed organic vesicles or matrices produced by the organism. The BIM processes are not controlled by the organism and the mineral particles typically have a large size distribution and no unique morphology. The BCM processes involve highly controlled mineralization and the particles often have a narrow size distribution. Much of the current research on biomineralization phenomena is directed at elucidating the structure of the organic macromolecules involved in the BCM processes and the nature of the organic-inorganic interactions.

The formation of ferric oxy-hydroxides by the iron-bacteria Leptothrix and Gallionella has some characteristics of BCM processes. The mineral is formed extracellularly by the hydrolysis and precipitation of ferric ions resulting from the bacterial oxidation of ferrous ions. The mineral particles themselves are indistinguishable from particles formed by purely inorganic hydrolysis. Yet the precipitate is molded into sheaths and stalks, presumably by organic molecules on the outer surface of the cell. In a strict sense, all oxidation of ferrous ions in solution by air and subsequent precipitation of ferric oxyhydroxides is a BIM process because oxygen in the atmosphere is a biological product.

Magnetite $\left(\mathrm{Fe}_{3} \mathrm{O}_{4}\right)$ formation by bacteria occurs by both BIM and BCM processes, with dissimilatory iron-reducing bacteria and magnetotactic bacteria, respectively. The dissimilatory iron-reducing bacteria ${ }^{26,27}$ respire $\mathrm{Fe}^{3+}$ in the form of amorphous ferric oxy-hydroxide, and export ferrous ions into the environment where they presumably interact with excess ferric oxy-hydroxide to produce magnetite. The ferrous ions can also interact with carbonate in the medium to form ferrous carbonate, siderite 22 . Magnetotactic bacteria form magnetite in intracellular membrane vesicles, from a ferric oxy-hydroxide precursor and ferrous ions ${ }^{12}$. Under certain culture conditions, they can also export $\mathrm{Fe}^{2+}$ into the medium, resulting in the formation of ferrous phosphate, vivianite, presumably by a BIM process 23 . The structures and magnetic properties of the magnetite particles produced by the BIM and BCM processes have characteristic differences ${ }^{28}$.

Iron sulfide formation by bacteria also occurs by both BIM and BCM processes, with sulfate-reducing bacteria in marine sediments and magnetotactic bacteria from high sulficle environments, respectively.

Iron biomineral formation in eukaryotic organisms is almost exclusively 
BCM. Ferritin formation involves a protein vesicle that controls the deposition of ferrihydrite. In this case, the protein may also function to prevent the formation of more intractable minerals such as hematite, $\mathrm{Fe}_{2} \mathrm{O}_{3}$, or magnetite, to facilitate iron mobilization from ferritin when required by the organism. Bacterioferritin functions in a similar manner. Ferritin also serves as a precursor to the formation of iron biominerals on the radular teeth of chitons and limpets. The final product, either magnetite or goethite, is deposited in an organic matrix on the tooth. Ferric oxy-hydroxide and lepidocrocite are involved at intermediate stages of the process.

\section{EVOLUTION OF IRON BIOMINERALIZATION}

Isotopic analysis of Precambrian sulfide minerals shows that $\mathrm{S}^{32}$, the light isotope of sulfur, is preferentially enriched compared to the heavy isotope, $\mathrm{S}^{34}$, in deposits younger than 2.7 Byr BP (billion years before present). This is evidence for biological intervention in the production of sulfide, and suggests that iron sulfide biomineralization by BIM processes is at least that old ${ }^{1}$. Since the magnetotactic bacteria that form iron-sulfide particles are found in sulfiderich environments, $\mathrm{BCM}$ of iron-sulfides could be equally ancient.

BIM of iron oxides and oxy-hydroxides certainly dates back at least to 2.0 Byr BP, when free oxygen began to accumulate in the earth's atmosphere as a result of bacterial photosynthesis. Since magnetite production in bacteria can occur anaerobically 13 as well as microaerobically 12, BCM of iron oxides could have originated at the same time or even earlier. In fact, Chang and Kirschvin $\mathrm{k}^{29}$ have reported the extraction of magnetite particles resembling those in modern magnetotactic bacteria from Precambrian rocks. Iron biominerals formed by BIM and/or BCM processes could have been incorporated into the unusual iron-rich sedimentary deposits known as the banded-iron formations, which were deposited between 3.8 and 1.6 Byr BP.

\section{REFERENCES}

1. H. A. Lowenstam and S. Weiner (1989) On Biomineralization, Oxford University Press, Oxford, 324 pages.

2. K. Simkiss and K. M. Wilbur (1989) Biomineralization, Academic Press, N.Y., 337 pages.

3. S. Mann, J. Webb and R. J. P. Williams, Editors, (1989) Biomineralization, VCH, Weinheim, 541 pages.

4. H. L. Ehrlich (1981) Geomicrobiology, Dekker, New York, 393 pages.

5. H. A. Lowenstam and G. R. Rossman (1975) Chem. Geol. 15: 15-51.

6. P. J. Artymiuk et al., this volume.

7. E. C. Theil and D. E. Sayers, this volume.

8. E. I. Stiefel and G. D. Watt (1979) Nature (London) 279: 81-83.

9. J. M. A. Smith et al., this volume.

10. J. Webb et al., this volume.

11. P. van der Wal, this volume.

12 R. P. Blakemore, this volume.

13. D. A. Bazylinski, this volume.

14. H. Vali and J. L. Kirschvink, this volume.

15. D. M. S. Esquivel et al., this volume.

16. N. H. C. Sparks, this volume.

17. J. L. Kirschvink, D. S. Jones, and B. J. MacFadden, Editors, (1985) Magnetite Biomineralization and Magnetoreception in Organisms. A New Biomagnetism,. Plenum Press, New York, 682 pages. 
18. P. A. Trudinger, I. B. Lambert, and G. W. Skyring (1972) Econ. Geol. 67: 1114.

19. H. E. Jones, P. A. Trudinger, L. A. Chambers and N. A. Pyliotis (1976) Z. Allg. Mikrobiol. 16: 425.

20. D. A. Bazylinski et al., this volume.

21. H. G. P. Lins de Barros et al., this volume.

22. N. H. C. Sparks, S. Mann, D. A. Bazylinski, D. R. Lovley, H. W. Jannasch, and R. B. Frankel (1990) Earth Planet. Sci. Letters 98: 14-22.

23. R. P. Blakemore and R. B. Frankel (1989) in Metal-Microbe Interactions, Edited by R. K. Pool and G. Gadd, I R L Press, Oxford, pp. 85-98.

24. H. A. Lowenstam (1981) Science 244: 126-139.

25. S. Mann (1986) J.Inorg. Biochem. 28: 363-371.

26. D. R. Lovley, this volume.

27. C. R. Myers and K. H. Nealson, this volume.

28. B. M. Moskowitz, R. B. Frankel, D. A. Bazylinski, H. W. Jannasch and D. R. Lovley (1989) Geophys. Res. Letters 16: 665-668.

29. S. Chang and J. L. Kirschvink (1989) Ann. Rev. Earth Planet. Sci. 17: 69-195. 